Article

\title{
Challenges of the Sharing Economy for SMEs: A Literature Review
}

\author{
Zuzana Soltysova *(D) and Vladimir Modrak $(\mathbb{D}$ \\ Faculty of Manufacturing Technologies, Technical University of Kosice, 08001 Presov, Slovakia; \\ vladimir.modrak@tuke.sk \\ * Correspondence: zuzana.soltysova@tuke.sk
}

Received: 1 July 2020; Accepted: 6 August 2020; Published: 12 August 2020

\begin{abstract}
The sharing economy is becoming increasingly popular in many sectors also thanks to the fact that not only young generation, but people of almost all ages are digitally literate, and therefore they readily participate in sharing economy practices. A very important part of their motivation comes from the knowledge that it is a great way to save money, but a no less important reason is the philosophical aspect, which is consistent with efforts to promote more sustainable consumption practices that prioritize access over ownership. The sharing economy has become a subject of interest not only among researchers and practitioners but also among policymakers and stakeholders who are concerned about the further extension of digital ecosystems. Fortunately, theorists from many fields, such as the commercial economy, gift economy, entrepreneurship, digital transformation, etc., pay due attention to this phenomenon. However, there is still room for focused exploration of this entrepreneurial and innovative approach from specific views in order to bring useful findings and insights on given issues. The intention of this study is to analyze the existing related literature and categorize sharing economy-based business models in relation to traditional business models. Potentially, this study can also contribute to a better understanding of the perspectives of the sharing economy in the transition of SMEs towards the Industry 4.0 paradigm.
\end{abstract}

Keywords: sharing economy; business models; SMEs; qualitative approach; quantitative approach

\section{Introduction}

The sharing economy (SE) is considered to be one of the topical issues of the Industry 4.0 strategic line, and not only for this reason it might be a subject of interest for small and medium enterprises. In addition, global markets are turbulent systems that call for permanent adaptation of new practices into existing business models or development of new business models. For example, we are victims of incorporation of mass-customization in product design, which enables consumers to co-design their products and be part of the creative process [1]. Similarly, SE should be perceived as a promising challenge for small and medium enterprises (SMEs). As is known, the sharing economy leads to a new way of economic thinking, meaning that things are preferably shared, borrowed and leased instead of owned. SMEs that are less competitive compared to large sized organizations are facing difficulties in securing human resources, capital, and technology and therefore are naturally reliant on intensive collaboration and integration with business partners to counter their limitations [2]. Moreover, SMEs can succeed in their development with more flexible implementation of the newest trends and technologies. In spite of the fact that the SE phenomena is quite widely covered in almost all its aspects in the scientific literature, there is not distinct categorization of its possible modes, and also an explanation of how SE-based business models relate to traditional entrepreneurial businesses is missing. For this reason, implementation of the SE practice into SMEs is rather not simple at all. In order to overcome the lack of knowledge and understanding, the challenge of this phenomena for 
SMEs, the aim of this paper is to analyze SE based business practices from two main perspectives, namely categorization of sharing practice types and their relations to traditional business models. The motivation of this research is awareness of the importance of such views on this phenomenon, since obtained findings can help practitioners to facilitate their transition towards advanced manufacturing and/or service practices.

The rest of this paper is devoted to analyzing the sharing business models literature in order to map its rapid growth, and also to analyze relations between different sharing-based business models and related complementary traditional business models. Subsequently, existing traditional business models are analyzed in terms of how they can be adopted for implementing features of advanced business models. Finally, decisive features and perspectives of SE will be outlined in the discussion and conclusions sections.

\section{Methodological Framework}

In order to structure and analyze the existing literature on sharing business models, our intention was to start with a qualitative study of the sources, and then to take a quantitative approach. The purpose of the qualitative study was to firstly analyze differences between so called traditional sharing approaches, which are typically based on ownership and are practiced within families and communities as a natural human behavior, against platform-based sharing economy business models, which are powered by disruptive digital innovations. Subsequently, we categorized platform-based sharing economy business models into three types in order to identify how they mutually relate with typical marketplaces.

Quantitative analysis of the existing literature included the mapping of the number of related publications by years. This view provided information about the adoption and diffusion of sharing economy ideas among different research disciplines. Finally, the main focus was on mapping and analyzing literature sources directly related to SMEs. Compiled knowledge from the analyzed sources was subsequently exploited to find answers to the following research questions (RQs):

RQ1: What are possible ways for SMEs to implement the sharing economy?

RQ2: What should motivate SMEs to implement sharing economy business models?

\section{Review on Sharing Business Models Literature}

\subsection{A Qualitative Approach}

The term "sharing" has become very popular in recent times, but this term is frequently used in different contexts. One can see this concept in the past where, for instance, overconsumption in households leads to sharing practice to use their resources more efficiently. In this case, we are talking about traditional sharing. However, commonly people act in their self-interest solely no matter what it means for future prospects, assuming that Earth's resources are diminishing. On the other hand, when sharing becomes a group effort, then such practice brings positive results for everyone. Here the important question obtrudes itself: What stimulated the rise of this new business paradigm as an alternative way of consuming? Firstly, the rapid development of platform-based businesses as enablers of SE has been driven by the internet and mobile apps. Secondly, the changing nature of the business environment itself brings to the table completely new ways of competition as a result of the disruptive innovations [3]. Finally, as consequence of these factors, the right to access a product or resource is considered of greater importance than the right to possess a product or resource.

SE can be defined, for example, as "a marketplace that consists of entities that innovatively and sustainably shape how marketing exchanges of valuable products and resources are produced and consumed through sharing, which can occur when entities take part in the actual or life-cycle use of a product or resource and communicate some form of information, and which can be scaled using technology" [4]. In view of the need to establish a working definition of what a sharing-based business 
model means from our perspective, it can be defined as building agreements between a service provider and clients through specific web platform(s) and mobile app(s).

Simple evidence that the sharing economy phenomena determines further business development is that we can see its manifestation in our daily lives. Moreover, sharing economy practice becomes an important driver of local economies, which can be documented, for example, by the fact that in Europe alone, sharing economy platforms generated revenues of nearly four billion euros and transactions of over 28 billion euros [5].

Sharing economy development is adequately supported through scientific and popular literature. It is useful to note that different authors use several synonymous terms describing these phenomena. Some of them can be mentioned here. Botsman and Rogers [6] describe this as "collaborative consumption"; Lamberton and Rose [7] as "commercial sharing systems"; Humphreys and Grayson [8] as "co-production"; Lanier and Schau [9] and Prahalad and Ramaswamy [10] as "co-creation"; Katz [11] and Lobel [12] as "platform economy"; Mont [13] as "product-service systems"; Bardhi and Eckhardt [14] as "access-based consumption,"; Fitzsimmons [15] as "consumer participation"; Schor [16] and Frenken and Schor [17] as "stranger sharing"; and Postigo [18] as "online volunteering". In order to extract specific knowledge from the existing literature, the term sharing economy will be further divided into two main sub-categories: traditional sharing practice (TSP) and SE [19]. While in traditional approach, products and services are shared based on mutual deals or agreements between both sides of consumers, SE uses payments and feedback or complaints through the platforms based on Web 2.0 technologies [20]. The concept based on the sharing economy has opened the doors to the rise of numerous for-profit and non-profit businesses. However, there is some confusion or skepticism about this business phenomena among academics and the public due to, for example, the lack of taxation rules for new Internet business models. This problem concerns especially actors at the municipal level and state levels.

Belk [21] differentiates the terms sharing and pseudo-sharing by using an epistemological viewpoint. He explains that traditional sharing is about helping and building human relations, while pseudo-sharing is a business relationship masquerading as communal sharing. As was mentioned, traditional sharing is about solving problems related to overconsumption and efficient resource usage. Typical characteristics and differences between TSP and SE are discussed by Demary [22]. According to her, SE companies present an important part of the business model portfolio, and thanks to them, competition in most markets in which they are active is significantly increased.

A common necessary precondition for both business models, i.e., TSP and SE, is trust between sharers and providers. However, the ways of gaining trust in these two models differ, as is shown in Figure 1.

a)

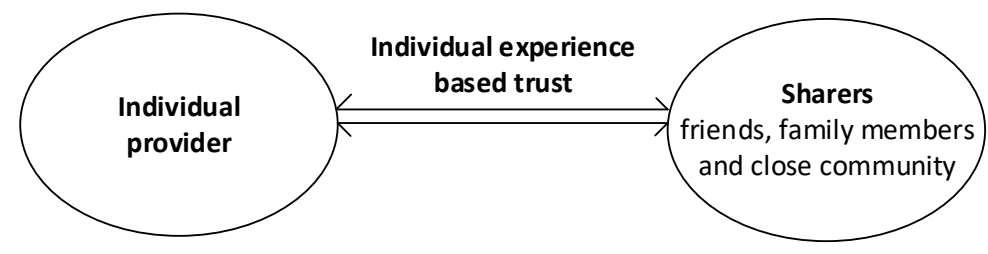

b)

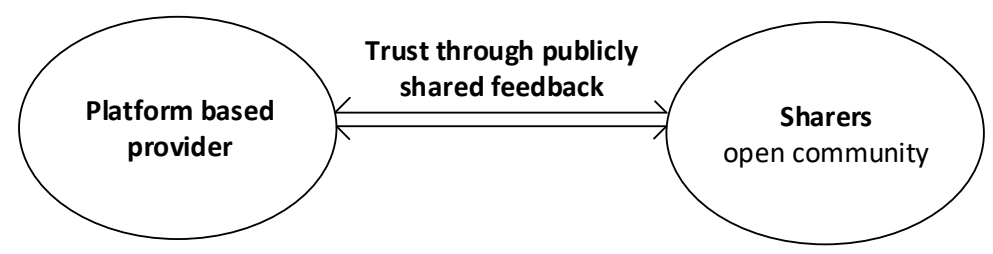

Figure 1. Ways of gaining trust (a) in traditional sharing practice, and (b) in sharing economy.

Frenken et al. [23] identified three types of SE business models, which are on demand-based sharing economy, product-service-based sharing economy, and second-hand-based sharing economy. 
In line with this categorization, the following classification of SE business models can be offered (see Figure 2).

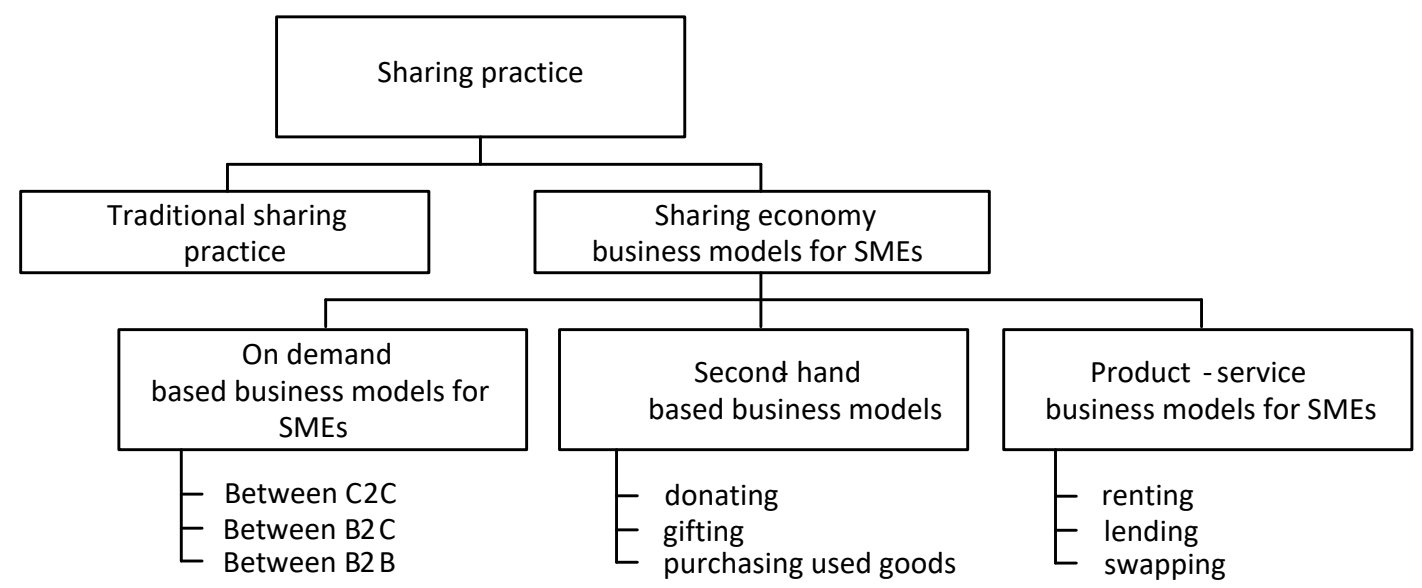

Figure 2. Basic classification of sharing practice types (adopted from [22,23]). Note: small and medium enterprises (SMEs); consumer-to-consumer (C2C); business-to-consumer marketplace (B2C); business-to-business (B2B).

The typical features of sharing business models depicted in Figure 2 are as follows:

On demand based sharing business model uses web platforms and apps and presents the intersection of tendencies towards the peer-to-peer (P2P) or consumer-to-consumer (C2C) exchange and access economy. For example, when ordering the taxi through, for example, the Uber company or Blablacar company.

Second-hand based sharing business model can be characterized as traditional second-hand business extended through web platforms and apps. A typical provider of services based on this business model is Momox $\mathrm{GmbH}$ company, which offers an online buying-and-selling service for second-hand garments across some Western Europe countries. Other well-known web based platforms are, for example, eBay or Facebook.

Product-service sharing business models are based on leasing a good from a company on a business-to-consumer marketplace (B2C)/consumer-to-business marketplace (C2B) rather than C2C. A consumer utilizing this business model obtains temporary access to a product, while the company retains ownership. An example is car-rental via Hertz or Zipcar.

In order to help SMEs to follow the above described business models, it is useful to identify their relations with different online marketplaces. For this purpose, the following comparison of sharing practice types is provided in Table 1.

Table 1. Sharing practice types in three marketplaces.

\begin{tabular}{cccccc}
\hline \multirow{2}{*}{ Sharing Practice Types } & Web Platform & \multicolumn{3}{c}{ Marketplace Type } \\
\cline { 3 - 5 } Based & C2C & B2C/C2B & B2B \\
\hline \multicolumn{2}{c}{ Traditional sharing practice } & - & Yes & - & - \\
\hline \begin{tabular}{c} 
Sharing \\
economy \\
\cline { 3 - 6 }
\end{tabular} & $\begin{array}{c}\text { Second-hand based sharing } \\
\text { business models } \\
\text { business models }\end{array}$ & Yes & Yes & Yes & Yes \\
\cline { 2 - 6 } & $\begin{array}{c}\text { Product-service sharing } \\
\text { business models }\end{array}$ & Yes & Yes & - & Yes \\
\hline
\end{tabular}


The most relevant sharing business models for transition of SMEs towards sharing businesses are those that operate on $\mathrm{B} 2 \mathrm{~B}$ and $\mathrm{C} 2 \mathrm{C}$ marketplaces. $\mathrm{C} 2 \mathrm{C}$ sharing business models are mostly based on virtual networks, through which individual consumers and individual suppliers are connected.

Similarly, for the same reason, transition of SMEs into smart organizations is considered to be also suitable in the case of B2C/C2B marketplace models. Naturally, it requires the adoption of e-business solutions, allowing many SMEs to respond to these challenging opportunities [24]. Nevertheless, the number of B2B sharing marketplace platforms, where one business system sells goods and services to other business systems, is still low compared to their B2C and C2C counterparts. The reason for this is likely that implementation of the B2B sharing model in SMEs requires combination with complementary innovation-based business models, what is especially challenging for innovation-oriented SMEs.

\subsection{A Quantitative Approach}

Due to the fact that a given domain is widely discussed in the literature, the quantitative review is an efficient way to analyze research directions and anticipated tendencies. In this order, we started with mapping of the number of related publications by years. For this purpose, the Web of Science (WOS) database was chosen. The Web of Science database is one of the most popular multidisciplinary databases among the scientific research community. This database offers to researchers a unified platform to allow for a wide variety of search terms across disciplines; links to regional citation indexes, patent data, specialized subject indexes, and an index of research data sets; and complete bibliographic data and author abstracts. Using the WOS database, researchers can find publications by author name, title, and institution, as well as by cited authors.

Firstly, we formulated the search strategy by finding publications related to the term "sharing economy" as part of the title or abstract, or as a keyword on the Web of Science portal. Then, a total of 2072 potentially relevant papers were found through this database, of which 595 publications were open access. Distribution of papers by years of publication is graphically depicted in Figure 3.

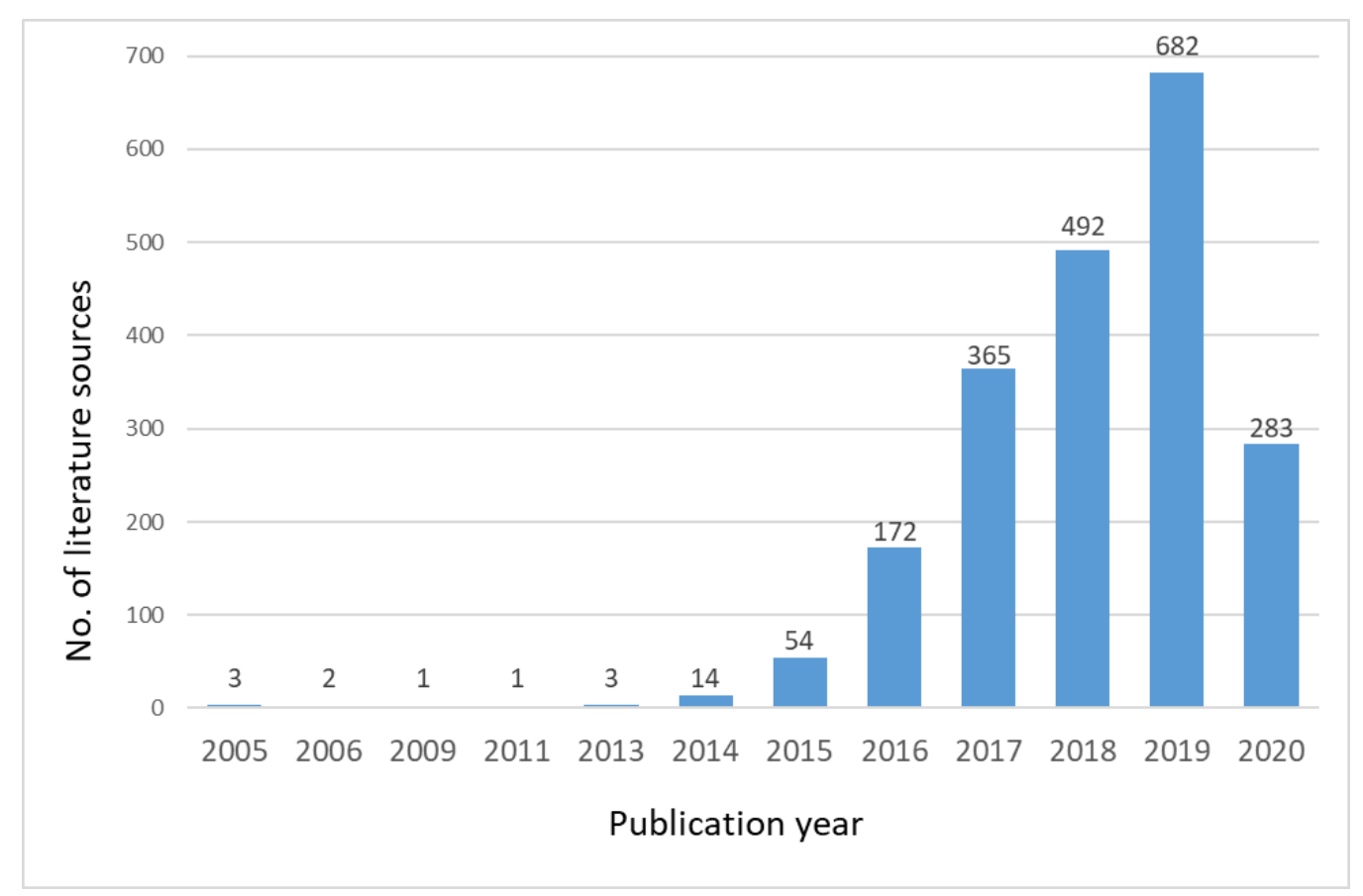

Figure 3. Distribution of the related papers by year of publication.

The literature sources included in Figure 3 consist of journal articles (1500 papers); conference proceedings articles (425 papers); book chapters (76 items); review articles (68 papers); editorial materials (63 papers); and book reviews and books ( 26 papers). 
In the next step, from the journals papers were selected only papers of the top ten journals. Subsequently, the ten journals were arranged by number of papers published in these journals in descending order, namely Sustainability (101 papers); International Journal of Hospitality Management (48 papers); Journal of Cleaner Production (48 papers); International Journal of Contemporary Hospitality Management (32 papers); Current Issues in Tourism (29 papers); Advances in Social Education and Humanities Research (27 papers); Technological Forecasting and Social Change (25 papers); Tourism Management (22 papers); Annals of Tourism Research (20 papers); and the Cambridge Handbook of the Law of the Sharing Economy (20 papers). A distribution of the journal papers according to this categorization, including journal impact factor (IF), is shown graphically in Figure 4.

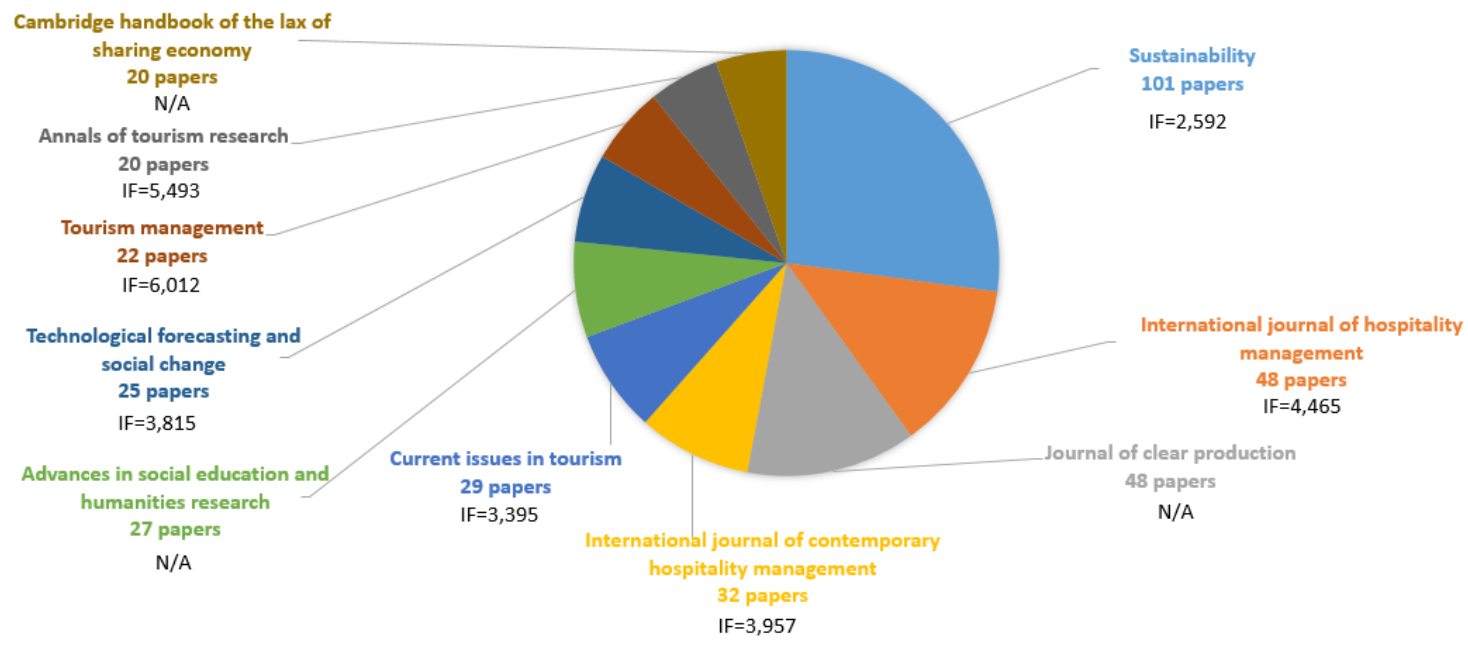

Figure 4. A distribution of the journal papers according to the number of items published in selected journals.

Finally, distribution of literature sources with respect to the top 15 research areas according to WOS classification is provided in Table 2. As the table shows, 769 papers are related to business economics; 390 papers to social sciences; 310 papers to computer science; 286 papers to environmental sciences ecology; 263 papers to engineering; 216 papers to science technology; 126 papers to government law; 76 papers to transportation; 75 papers to operations research and management science; 74 papers to sociology; 71 papers to geography; 67 papers to public administration; 61 papers to information science and library science; 59 papers to telecommunications; and 52 papers to urban studies.

Table 2. Distribution of literature sources into research disciplines with description of their orientation field.

\begin{tabular}{|c|c|c|}
\hline Research Discipline & $\begin{array}{l}\text { Number of } \\
\text { Publications }\end{array}$ & Main Domains Treated in the Publications \\
\hline $\begin{array}{c}\text { Business economics } \\
\text { e.g., }[20,25,26]\end{array}$ & 769 & $\begin{array}{l}\text { Analysis of selected marketplaces; } \\
\text { Some papers are in relation to tourism; } \\
\text { Analysis of the influences of Airbnb on hotels; } \\
\text { Description of sharing economy effects; } \\
\text { Mapping out the sharing economy; } \\
\text { Business models for the sharing economy; } \\
\text { Sustainability of sharing economy; } \\
\text { Pricing strategy in relation to sharing economy. }\end{array}$ \\
\hline $\begin{array}{c}\text { Social sciences } \\
\text { e.g., [27-29] }\end{array}$ & 390 & $\begin{array}{c}\text { Analysis of the future of the sharing economy; } \\
\text { Description of customers' satisfaction with accommodation; } \\
\text { Analysis of customers' perspectives; } \\
\text { Trust and reputation in the sharing economy; } \\
\text { Analysis of review comments; } \\
\text { Examining the ever-increasing popularity of Airbnb; } \\
\text { Mapping Airbnb in countries. }\end{array}$ \\
\hline
\end{tabular}


Table 2. Cont.

\begin{tabular}{|c|c|c|}
\hline Research Discipline & $\begin{array}{l}\text { Number of } \\
\text { Publications }\end{array}$ & Main Domains Treated in the Publications \\
\hline $\begin{array}{l}\text { Computer science } \\
\text { e.g., [30-32] }\end{array}$ & 310 & $\begin{array}{c}\text { Intermediation in a sharing economy; } \\
\text { Analysis of block chain technologies for an advanced and } \\
\text { cyber-resilient automotive industry; } \\
\text { Framework for sharing economy based on IoT; } \\
\text { Designing markets with a focus on exchange platforms; } \\
\text { Recommendation system for sharing economy. }\end{array}$ \\
\hline $\begin{array}{l}\text { Environmental sciences } \\
\text { and ecology } \\
\text { e.g., [33-35] }\end{array}$ & 286 & $\begin{array}{l}\text { Analysis of motivation for intended sharing economy participation; } \\
\text { Examination of sustainable business models; } \\
\text { Sustainability analysis of sharing economy; } \\
\text { Focus on collaborative consumption and its motivation. }\end{array}$ \\
\hline $\begin{array}{l}\text { Engineering } \\
\text { e.g., [36-38] }\end{array}$ & 263 & $\begin{array}{l}\text { Understanding the sharing economy drivers and impediments; } \\
\text { Marketing research on product design; } \\
\text { Exploration of sharing economy opportunities in the } \\
\text { electricity sector; } \\
\text { Strategies based on sharing economy to manufacturers; } \\
\text { Value creation in production. }\end{array}$ \\
\hline $\begin{array}{l}\text { Science technology } \\
\text { e.g., [39-41] }\end{array}$ & 216 & $\begin{array}{l}\begin{array}{l}\text { Creation of framework adopting the multi-level socio-technical } \\
\text { transition theory. }\end{array}\end{array}$ \\
\hline $\begin{array}{l}\text { Government law } \\
\text { e.g., }[42-44]\end{array}$ & 126 & $\begin{array}{c}\text { Exploration of conflicts between business and government related } \\
\text { to sharing economy; } \\
\text { Description of new regulators in cities; } \\
\text { Comparison of home sharing and sharing economy; } \\
\text { Law and sharing economy; } \\
\text { Role of the government and legislation issues in the } \\
\text { sharing economy. }\end{array}$ \\
\hline
\end{tabular}

\section{Transportation}

e.g., [45-47]

Overview on shared ride sourcing systems;

Uncovering motives of business-to-consumer and peer-to-peer car sharing adopters;

Offering of vehicle-to-vehicle wireless power transfer;

Description of sharing economy implications in transport sector;

Presentation of various kinds of ride sharing.

\begin{tabular}{|c|c|c|}
\hline $\begin{array}{l}\text { Operations research and } \\
\text { management science } \\
\text { e.g., }[48-50]\end{array}$ & 75 & $\begin{array}{l}\text { Optimal investment strategy for sharing platform; } \\
\text { Development of analytical framework to select business modes } \\
\text { under the sharing economy; } \\
\text { Description of classical operations management theory and models, } \\
\text { which can be used to study applications of sharing economy. }\end{array}$ \\
\hline $\begin{array}{l}\text { Sociology } \\
\text { e.g., [51-53] }\end{array}$ & 74 & $\begin{array}{l}\text { Impact of sharing economy on exchange of moral values; } \\
\text { Post-failure loyalty in the sharing economy. } \\
\text { Analysis of ethnic discrimination in the sharing economy; } \\
\text { Exploration of tourists' willingness in providing negative reviews } \\
\text { online to express poor experiences. }\end{array}$ \\
\hline $\begin{array}{l}\text { Geography } \\
\text { e.g., [54-56] }\end{array}$ & 71 & $\begin{array}{l}\text { Digital reputation issues and platform-based tourism; } \\
\text { Description of sharing economy usage in diverse countries; } \\
\text { Exploring the regional impact of Airbnb on urban environments. }\end{array}$ \\
\hline $\begin{array}{l}\text { Public administration } \\
\text { e.g., [57-59] }\end{array}$ & 67 & $\begin{array}{l}\text { Examination of consumers' value co-creation in sharing economy; } \\
\text { Description of civil opportunities in collaborative economy based on } \\
\text { sharing economy. }\end{array}$ \\
\hline $\begin{array}{l}\text { Information science and } \\
\text { library science } \\
\text { e.g., [60-62] }\end{array}$ & 61 & $\begin{array}{l}\text { Sharing economy literature reviews; } \\
\text { Framework for future research, study the role of big data analytics } \\
\text { in sharing economy. }\end{array}$ \\
\hline $\begin{array}{l}\text { Telecommunications } \\
\text { e.g., [63-65] }\end{array}$ & 59 & $\begin{array}{l}\text { Description of cloud based sharing platforms; } \\
\text { Collaborative consumption through mobile apps; } \\
\text { Exploring service quality among online sharing economy platforms. }\end{array}$ \\
\hline $\begin{array}{l}\text { Urban studies } \\
\text { e.g., [66-68] }\end{array}$ & 52 & $\begin{array}{c}\text { Study the understanding the spatial distribution in ride-sharing; } \\
\text { Exploration of the ride-sharing adaption in urban areas of cities; } \\
\text { Discussion on sharing economy and its increasing impact on } \\
\text { planning policy and urban governance. }\end{array}$ \\
\hline
\end{tabular}


This quantitative overview of the related literature firstly showed that SE significantly attracted not only practitioners but also the scholarly community in recent years. This is clear evidence that SE phenomena cannot be perceived only as one of possible business approach, but on the contrary, SE-based business approaches vary depending on specific business conditions. Another interesting finding is that SE penetrated into wide research disciplines. This is quite promising, since it can lead to multidisciplinary exchanges of experiences and bring new stimulus for further development of this phenomena.

In line with the paper's research objectives, it was possible to extract from the all identified papers twelve papers directly related to SMEs in the nexus of sharing economy implications. These papers are listed in Table 3 with their short descriptions. Distribution of the papers by year is as follows: three articles published in the year 2020; five articles published in year the 2019; three papers published in the year 2018; and one paper published in the year 2017.

Table 3. List and description of papers related to implementing of sharing economy by SMEs.

\begin{tabular}{|c|c|c|}
\hline No. & Publication Title & Basic Characteristics \\
\hline 1 & $\begin{array}{l}\text { Achieving sustainable development goals through } \\
\text { identifying and analyzing barriers to industrial } \\
\text { sharing economy: A framework development [69] }\end{array}$ & $\begin{array}{l}\text { This paper specified the most common barriers of the } \\
\text { industrial sharing economy, and the authors propose } \\
\text { recommendations for the implementation of the sharing } \\
\text { economy by SMEs. }\end{array}$ \\
\hline 2 & $\begin{array}{l}\text { Corporate entrepreneurship, product innovation, } \\
\text { and knowledge conversion: the role of digital } \\
\text { platforms [70] }\end{array}$ & $\begin{array}{l}\text { This paper proposes the motivation, opportunity, and ability } \\
\text { model for implementing the sharing economy by SMEs. } \\
\text { Further, this model is verified through the three selected } \\
\text { SMEs. }\end{array}$ \\
\hline 3 & $\begin{array}{l}\text { Development of a business model by introducing } \\
\text { sustainable and tailor-made value proposition for } \\
\text { SME clients [71] }\end{array}$ & $\begin{array}{l}\text { Authors in this paper describe the introduction of platform } \\
\text { based business models and show how they contribute to } \\
\text { easier adaptation to new market conditions. }\end{array}$ \\
\hline 4 & $\begin{array}{l}\text { Cloud-based ubiquitous object sharing platform for } \\
\text { heterogeneous logistics system integration [72] }\end{array}$ & $\begin{array}{l}\text { This paper proposes a cloud-based ubiquitous object sharing } \\
\text { platform to simplify logistics system integration for SMEs. }\end{array}$ \\
\hline 5 & $\begin{array}{l}\text { Implementing a platform service based on the } \\
\text { sharing economy for supply chain operations of } \\
\text { small and medium enterprises [73] }\end{array}$ & $\begin{array}{l}\text { This paper is focused on the development of strategies to } \\
\text { integrate the main ideas of the sharing economy and their } \\
\text { platform-based business models into supply chain } \\
\text { management. }\end{array}$ \\
\hline 6 & Digital transformation process and SMEs [74] & $\begin{array}{l}\text { This paper provides a comprehensive overview of the } \\
\text { factors affecting the digital transformation process, and also } \\
\text { towards sharing business practices and describes the digital } \\
\text { transformation of the manufacturing sector in Turkey. }\end{array}$ \\
\hline 7 & $\begin{array}{l}\text { Who benefits from online financing? A sharing } \\
\text { economy E-tailing platform perspective [75] }\end{array}$ & $\begin{array}{l}\text { This paper is oriented to the online sharing economy system } \\
\text { which contains an e-tailing platform and a } \\
\text { budget-constrained small and medium-sized seller. }\end{array}$ \\
\hline 8 & $\begin{array}{l}\text { A conceptual framework for value co-creation in } \\
\text { service enterprises (Case of tourism agencies) [76] }\end{array}$ & $\begin{array}{l}\text { The authors developed a conceptual framework for value } \\
\text { co-creation in small- and medium-sized tourism agencies, } \\
\text { which is tested on } 23 \text { employees and managers. }\end{array}$ \\
\hline 9 & $\begin{array}{l}\text { Collaborative consumption for small- and } \\
\text { medium-sized enterprises in South Korea [77] }\end{array}$ & $\begin{array}{l}\text { This paper presents alternative approaches to revitalizing } \\
\text { the economy, and it also includes consideration of the } \\
\text { environmental and social impacts of the sharing economy on } \\
\text { the clothing industry. }\end{array}$ \\
\hline 10 & $\begin{array}{l}\text { Cloud asset-enabled integrated IoT platform for lean } \\
\text { prefabricated construction [78] }\end{array}$ & $\begin{array}{l}\text { This paper proposes an integrated cloud-based IoT platform } \\
\text { by exploiting the concept of cloud asset. }\end{array}$ \\
\hline 11 & $\begin{array}{l}\text { Funds sharing regulation in the context of the } \\
\text { sharing economy: Understanding the logic of } \\
\text { China's P2P lending regulation [79] }\end{array}$ & $\begin{array}{l}\text { This article scrutinizes the regulation of } \mathrm{P} 2 \mathrm{P} \text { lending in China. } \\
\text { The authors outline that the rigid rules placed on lending } \\
\text { platforms, limiting their ability to maintain their roles. }\end{array}$ \\
\hline 12 & $\begin{array}{l}\text { Particularities of doing business in Russia in the } \\
\text { conditions of sharing economy [80] }\end{array}$ & $\begin{array}{l}\text { This paper is focused on sharing economy conditions used } \\
\text { in Russia. The authors identified the most popular sectors } \\
\text { for small and medium businesses and identified the main } \\
\text { implementation problems. }\end{array}$ \\
\hline
\end{tabular}


Subsequently, these papers could be categorized into four groups according to the treated problems as depicted in Figure 5.

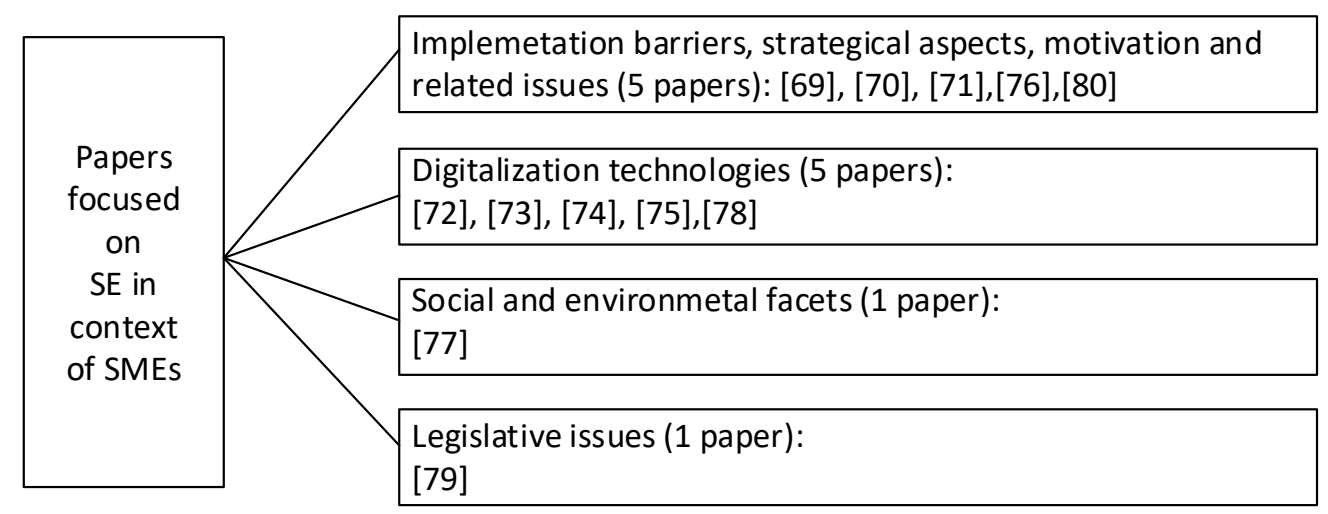

Figure 5. Categorization of papers according to research orientation.

Based on empirical experiences and by summing the existing knowledge from literature sources, the following answer to the RQ1 can be formulated: principally, there are two possible strategies for SMEs to implement SE. The first is the exploitation of at least one of the existing sharing economy platforms, and the second one is based on development of one's own SE platform. The main differences and common attributes of these two possible strategies are outlined in Table 4.

Table 4. Attributes of the two possible strategies based on sharing economy principles.

\begin{tabular}{cc}
\hline $\begin{array}{c}\text { Redesigned Business Model by Using } \\
\text { Existing Platform (Platform User) }\end{array}$ & $\begin{array}{c}\text { New Business Model Based by Development of } \\
\text { One's Own Platform (Platform Provider) }\end{array}$ \\
\hline $\begin{array}{c}\text { Selection from existing platforms } \\
\text { Does not require high demands on } \\
\text { digitalization and ICTs }\end{array}$ & Building the reputation \\
\hline Low investment requirements & High investment requirements \\
\hline $\begin{array}{c}\text { Does not require breakthrough product or } \\
\text { service innovations }\end{array}$ & Orientation on higher-level (disruptive) innovations \\
\hline $\begin{array}{c}\text { Requires only necessary ICT knowledge for } \\
\text { utilization of the existing platform }\end{array}$ & $\begin{array}{c}\text { Requires coordination between different stakeholders } \\
\text { on internal and external levels }\end{array}$ \\
\hline Does not require much time & Time-consuming process \\
\hline Data driven decision making \\
\hline Orientation on foreign partners \\
\hline Sharing experience and knowledge with each other \\
\hline
\end{tabular}

By extracting findings from the literature review in the context of what should motivate SMEs to implement sharing economy business models, it is possible to articulate answers to the RQ2 as follows:

SE brings new working opportunities for individuals as well as for SMEs;

SE impacts positively on environment and profitability;

SE is helping SMEs to ensure their company's survival.

\section{Discussion and Conclusions}

Initially, it is useful to state that the combination of quantitative and qualitative research methods offered in the presented study gave more comprehensive results than sole reliance on either a qualitative or quantitative approach. The main objective of the quantitative research approach was to classify 
literature sources based on common features, quantify them, and to identify the main domains treated in the publications, while in the case of the qualitative research approach, its main purpose was to understand the meaning of the term "sharing economy" itself; to explore the background of its development; to analyze what triggered its growth; and to outline also criticism for lack of international legislative definitions and legal frameworks for taxation. Moreover, based on qualitative analysis of the literature sources, it was possible to propose the classification of sharing economy business models, which can be relevant for SMEs (see Figure 2). In addition, the main differences between TSP and SE were identified in Figure 1. As can be seen from Figure 1, the basic building block of sharing practice is trust between sharers and providers. Paradoxically, trust between actors in SE can be easily achieved, and then between sharers and individual providers, since sharer feedback through platforms is published, while individual experience-based trust transferred among sharers is often accompanied by information noise. However, the proposed classification concept presents more or less our subjective view and therefore should be the focus of future work towards development of a classification reference model in order to provide representative categorization of platform-based business models.

As was pointed out, platform-based business models have a basis in traditional sharing approaches, and in a certain sense their "transformation" has been enabled by new information and communications technologies and global regulations. In order to show the differences existing between the traditional sharing and the platform based business models, the comparison along with identification of intersections between these two types of sharing practices is provided in Table 1 . This comparison shows that the B2B marketplace is among the most suitable environment for creation and development of sharing enterprises. Moreover, it is quite evident that if the sharing economy grows, it helps the unemployed or under-employed to create home-based business of the types $\mathrm{C} 2 \mathrm{C}$ or C2B. Therefore, platform-based business approaches are significantly supported in developed and emerging economies [81].

It is worth mentioning here that the sharing economy is a paradigmatic change for the better, since it is changing consumer behavior towards green practices. This a new trend where people prefer temporary access over ownership, which has an unambiguously positive impact on environmental sustainability. However, technological development, as a precondition of further development of SE, is not always positively perceived among people. This is due to the fact that advanced technology and related industrialization brought many negative impacts upon the environment. On the other hand, further technological development is considered as an important impetus to facilitate transition of SMEs towards the Industry 4.0 conception, which is considered as a sustainable growth factor, since this conception presents a stable element of circular economy. The root of this contradiction lies in the classical dilemma of what to prefer-technological development or environmental protection, but optimally both. Thus, thinking optimistically, further successful implementation of platform-based business models can offer significant benefits for everyone.

Author Contributions: V.M. proposed the whole structure of this paper, provided the introduction section, and summarized the findings in the conclusion section. V.M. and Z.S. contributed to the section "Review on sharing business models literature" in relation to the qualitative approach. Z.S. prepared the literature review based on the quantitative approach in the same section. All authors have read and agreed to the published version of the manuscript.

Funding: This research was funded by the KEGA project No. 025TUKE-4/2020 granted by the Ministry of Education of the Slovak Republic and by the European Union's Horizon 2020 research and innovation program under the Marie Skłodowska-Curie grant agreement No. 734713.

Conflicts of Interest: The authors declare no conflict of interest. 


\section{References}

1. Modrak, V.; Bednar, S.; Soltysova, Z. Application of axiomatic design-based complexity measure in mass customization. Procedia Cirp. 2016, 50, 607-612. [CrossRef]

2. Ślusarczyk, B. Prospects for the shared services centers development in Poland in the context of human resources availability. Pol. J. Manag. Stud. 2017, 15, 218-231. [CrossRef]

3. Dima, I.C.; Grabara, J.; Modrak, V.; Piotr, P.; Popescu, C. Using the expert systems in the operational management of production. In Proceedings of the 11th WSEAS International Conference on Mathematics and Computers in Business and Economics (MCBE'10), Iasi, Romania, 13-15 June 2010; WSEAS Press: Sitia, Greece, 2010; pp. 307-312.

4. Lim, W.M. Sharing economy: A marketing perspective. Australas. Mark. J. 2020, 1-10. [CrossRef]

5. Agarwal, N.; Steinmetz, R. Sharing Economy: A Systematic Literature Review. Int. J. Innov. Technol. Manag. (IJITM) 2019, 16, 1-17. [CrossRef]

6. Botsman, R.; Rogers, R. Beyond zipcar: Collaborative consumption. Harv. Bus. Rev. 2010, 88, 1-30.

7. Lamberton, C.; Rose, R. When is ours better than mine? A framework for understanding and altering participation in commercial sharing systems. J. Mark. 2012, 76, 109-125. [CrossRef]

8. Humphreys, A.; Grayson, K. The intersecting roles of consumer and producer: A critical perspective on co-production, co-creation and prosumption. Sociol. Compass 2008, 2, 963-980. [CrossRef]

9. Lanier, C., Jr.; Schau, H. Culture and co-creation: Exploring consumers' inspirations and aspirations for writing and posting on-line fan fiction. In Consumer Culture Theory: Research in Consumer Behavior; Belk, R., Sherry, J., Jr., Eds.; Elsevier: Amsterdam, The Netherlands, 2007; Volume 11, pp. 321-342.

10. Prahalad, C.K.; Ramaswamy, V. Co-creation experiences the net practice in value creation. J. Interact. Mark. 2004, 18, 5-14. [CrossRef]

11. Katz, V. Regulating the Sharing Economy. Berkeley Technol. Law J. 2015, 30, 1067-1126.

12. Lobel, O. The Law of the Platform. Minn. Law Rev. 2016, 101, 87-96.

13. Mont, O. Clarifying the concept of product-service system. J. Clean. Prod. 2002, 10, 237-245. [CrossRef]

14. Bardhi, F.; Eckhardt, G. Access based consumption: The case of car sharing. J. Consum. Res. 2012, 39, 881-898. [CrossRef]

15. Fitzsimmons, J. Consumer Participation and Productivity in Service Operations. Interfaces 1985, 15, 60-67. [CrossRef]

16. Schor, J. Debating the Sharing Economy. J. Self-Gov. Manag. Econ. 2016, 4, 7-22.

17. Frenken, K.; Schor, J. Putting the sharing economy into perspective. In A Research Agenda for Sustainable Consumption Governance; Edward Elgar Publishing: Cheltenham, UK, 2019; pp. 121-135.

18. Postigo, H. Emerging sources of labor on the Internet: The case of America Online volunteers. Int. Rev. Soc. Hist. 2003, 48, 205-223. [CrossRef]

19. Stanoevska-Slabeva, K.; Lenz-Kesekamp, V.; Suter, V. Platforms and the Sharing Economy: An Analysis EU H2020 Research Project Ps2Share: Participation, Privacy, and Power in the Sharing Economy, 2017. Available online: https://papers.ssrn.com/sol3/papers.cfm?abstract_id=3102184 (accessed on 1 July 2020).

20. Belk, R. You are what you can access: Sharing and collaborative consumption online. J. Bus. Res. 2014, 67, 1595-1600. [CrossRef]

21. Belk, R. Sharing versus pseudo-sharing in Web 2.0. Anthropologist 2014, 18, 7-23. [CrossRef]

22. Demary, V. Competition in the sharing economy. In Contributions to the Political Debate by the Cologne Institute for Economic Research; IW policy paper; Institut der deutschen Wirtschaft Köln: Köln, Germany, 2015; Volume 19, pp. 1-28.

23. Frenken, K.; Meelen, T.; Arets, M.; Van de Glind, P. Smarter Regulation for the Sharing Economy. The Guardian, 2015, Volume 20. Available online: https://www.theguardian.com/science/political-science/2015/may/20/ smarter-regulation-for-the-sharing-economy (accessed on 6 February 2017).

24. Gutowska, A.; Sloane, A. Modelling the B2C Marketplace: Evaluation of a Reputation Metric for e-commerce. In International Conference on Web Information Systems and Technologies; Springer: Berlin/Heidelberg, Germany, 2009; pp. 212-226.

25. Zervas, G.; Proserpio, D.; Byers, J.W. The rise of the sharing economy: Estimating the impact of Airbnb on the hotel industry. J. Mark. Res. 2017, 54, 687-705. [CrossRef] 
26. Cohen, B.; Kietzmann, J. Ride on! Mobility business models for the sharing economy. Organ. Environ. 2014, 27, 279-296. [CrossRef]

27. Ert, E.; Fleischer, A.; Magen, N. Trust and reputation in the sharing economy: The role of personal photos in Airbnb. Tour. Manag. 2016, 55, 62-73. [CrossRef]

28. Cheng, M. Sharing economy: A review and agenda for future research. Int. J. Hosp. Manag. 2016, 57, 60-70. [CrossRef]

29. Birinci, H.; Berezina, K.; Cobanoglu, C. Comparing customer perceptions of hotel and peer-to-peer accommodation advantages and disadvantages. Int. J. Contemp. Hosp. Manag. 2018, 30, 1190-1210. [CrossRef]

30. Hawlitschek, F.; Notheisen, B.; Teubner, T. The limits of trust-free systems: A literature review on blockchain technology and trust in the sharing economy. Electron. Commer. Res. Appl. 2018, 29, 50-63. [CrossRef]

31. Rahman, M.A.; Rashid, M.M.; Hossain, M.S.; Hassanain, E.; Alhamid, M.F.; Guizani, M. Blockchain and IoT-based cognitive edge framework for sharing economy services in a smart city. IEEE Access 2019, 7, 18611-18621. [CrossRef]

32. Kim, S.; Yoon, Y. Recommendation system for sharing economy based on multidimensional trust model. Multimed. Tools Appl. 2016, 75, 15297-15310. [CrossRef]

33. Lan, J.; Ma, Y.; Zhu, D.; Mangalagiu, D.; Thornton, T.F. Enabling value co-creation in the sharing economy: The case of mobike. Sustainability 2017, 9, 1504. [CrossRef]

34. Piscicelli, L.; Ludden, G.D.S.; Cooper, T. What makes a sustainable business model successful? An empirical comparison of two peer-to-peer goods-sharing platforms. J. Clean. Prod. 2018, 172, 4580-4591. [CrossRef]

35. Hawlitschek, F.; Teubner, T.; Gimpel, H. Understanding the sharing economy-Drivers and impediments for participation in peer-to-peer rental. In Proceedings of the 2016 49th Hawaii International Conference on System Sciences (HICSS), Koloa, HI, USA, 5-8 January 2016; IEEE: Piscataway, NJ, USA, 2016; pp. 4782-4791.

36. Luchs, M.G.; Swan, K.S.; Creusen, M.E.H. Perspective: A review of marketing research on product design with directions for future research. J. Prod. Innov. Manag. 2016, 33, 320-341. [CrossRef]

37. Cohen, B.; Munoz, P. Sharing cities and sustainable consumption and production: Towards an integrated framework. J. Clean. Prod. 2016, 134, 87-97. [CrossRef]

38. Lombardi, P.; Schwabe, F. Sharing economy as a new business model for energy storage systems. Appl. Energy 2017, 188, 485-496. [CrossRef]

39. Martin, C.J.; Upham, P.; Klapper, R. Democratising platform governance in the sharing economy: An analytical framework and initial empirical insights. J. Clean. Prod. 2017, 166, 1395-1406. [CrossRef]

40. Alanne, K.; Cao, S. Zero-energy hydrogen economy (ZEH2E) for buildings and communities including personal mobility. Renew. Sustain. Energy Rev. 2017, 71, 697-711. [CrossRef]

41. Deveci, M.; Canitez, F.; Gokasar, I. WASPAS and TOPSIS based interval type-2 fuzzy MCDM method for a selection of a car sharing station. Sustain. Cities Soc. 2018, 41, 777-791. [CrossRef]

42. Posen, H.A. Ridesharing in the sharing economy: Should regulators impose Uber regulations on Uber. Iowa Law Rev. 2015, 101, 405-433.

43. Miller, S.R. First principles for regulating the sharing economy. Harv. J. Legis. 2016, 53, 149-202. [CrossRef]

44. Lougher, G.; Kalmanowicz, S. EU competition law in the sharing economy. J. Eur. Compet. Law Pract. 2016, 7, 87-102. [CrossRef]

45. Birdsall, M. Carsharing in a sharing economy. Inst. Transp. Eng. ITE J. 2014, 84, 37-40.

46. Abdolmaleki, M.; Masoud, N.; Yin, Y. Vehicle-to-vehicle wireless power transfer: Paving the way toward an electrified transportation system. Transp. Res. Part C Emerg. Technol. 2019, 103, 261-280. [CrossRef]

47. Standing, C.; Standing, S.; Biermann, S. The implications of the sharing economy for transport. Transp. Rev. 2019, 39, 226-242. [CrossRef]

48. Bellos, I.; Ferguson, M.; Toktay, L.B. The car sharing economy: Interaction of business model choice and product line design. Manuf. Serv. Oper. Manag. 2017, 19, 185-201. [CrossRef]

49. Sun, X.; Tang, W.; Chen, J.; Zhang, J. Optimal investment strategy of a free-floating sharing platform. Transp. Res. Part E Logist. Transp. Rev. 2020, 138, 1-18. [CrossRef]

50. Benjaafar, S.; Hu, M. Operations management in the age of the sharing economy: What is old and what is new? Manuf. Serv. Oper. Manag. 2020, 22, 93-101. [CrossRef]

51. Shuqair, S.; Pinto, D.C.; Mattila, A.S. Benefits of authenticity: Post-failure loyalty in the sharing economy. Ann. Tour. Res. 2019, 78, 1-15. [CrossRef] 
52. Tjaden, J.D.; Schwemmer, C.; Khadjavi, M. Ride with me-Ethnic discrimination, social markets, and the sharing economy. Eur. Sociol. Rev. 2018, 34, 418-432. [CrossRef]

53. Fitzmaurice, C.J.; Ladegaard, I.; Attwood-Charles, W.; Cansoy, M.; Carfagna, L.B.; Schor, J.B.; Wengronowitz, R. Domesticating the market: Moral exchange and the sharing economy. Socio-Econ. Rev. 2020, 18, 81-102. [CrossRef]

54. Lima, V. Towards an understanding of the regional impact of Airbnb in Ireland. Reg. Stud. Reg. Sci. 2019, 6, 78-91. [CrossRef]

55. Crommelin, L.; Troy, L.; Martin, C.; Pettit, C. Is Airbnb a sharing economy superstar? Evidence from five global cities. Urban Policy Res. 2018, 36, 429-444. [CrossRef]

56. Celata, F.; Capineri, C.; Romano, A. A room with a (re) view. Short-term rentals, digital reputation and the uneven spatiality of platform-mediated tourism. Geoforum 2020, 112, 129-138. [CrossRef]

57. Nadeem, W.; Juntunen, M.; Shirazi, F.; Hajli, N. Consumers' value co-creation in sharing economy: The role of social support, consumers' ethical perceptions and relationship quality. Technol. Forecast. Soc. Chang. 2020, 151, 1-13. [CrossRef]

58. Zoltan, S.; Yoo, J. Sharing economy: Civil opportunities in collaborative economy. Civ. Szle. 2015, 12, 75-94.

59. Mair, J.; Reischauer, G. Capturing the dynamics of the sharing economy: Institutional research on the plural forms and practices of sharing economy organizations. Technol. Forecast. Soc. Chang. 2017, 125, 11-20. [CrossRef]

60. Sutherland, W.; Jarrahi, M.H. The sharing economy and digital platforms: A review and research agenda. Int. J. Inf. Manag. 2018, 43, 328-341. [CrossRef]

61. Constantiou, I.; Marton, A.; Tuunainen, V.K. Four models of sharing economy platforms. MIS Q. Exec. 2017, 16, 231-251.

62. Albergaria, M.; Jabbour, C.J.C. The role of big data analytics capabilities (BDAC) in understanding the challenges of service information and operations management in the sharing economy: Evidence of peer effects in libraries. Int. J. Inf. Manag. 2020, 51, 1-13. [CrossRef]

63. Li, Y.; Zhu, L.; Shen, M.; Gao, F.; Zheng, B.; Du, X.; Yin, S. CloudShare: Towards a Cost-Efficient and Privacy-Preserving Alliance Cloud Using Permissioned Blockchains. In International Conference on Mobile Networks and Management; Springer: Cham, Switzerland, 2017; pp. 339-352.

64. Inagaki, Y.; Shinkuma, R. Authentication Control System for Mobile Device Sharing Based on Online Social Relationships. In Proceedings of the GLOBECOM 2017-2017 IEEE Global Communications Conference, Singapore, Singapore, 4-7 December 2017; IEEE: Piscataway, NJ, USA, 2017; pp. 1-6.

65. Zhang, Y.; Phang, C.W.; Gu, R.; Zhang, C. Antecedents and role of individual sociability on participation in mobile collaborative consumption. Internet Res. 2019, 29, 1064-1089. [CrossRef]

66. Ferreri, M.; Sanyal, R. Platform economies and urban planning: Airbnb and regulated deregulation in London. Urban Stud. 2018, 55, 3353-3368. [CrossRef]

67. Ampudia-Renuncio, M.; Guirao, B.; Molina-Sánchez, R.; de Álvarez, C.E. Understanding the spatial distribution of free-floating carsharing in cities: Analysis of the new Madrid experience through a web-based platform. Cities 2020, 98, 1-16. [CrossRef]

68. Aguilera-Garcia, A.; Gomez, J.; Sobrino, N. Exploring the adoption of moped scooter-sharing systems in Spanish urban areas. Cities 2020, 96, 1-13. [CrossRef]

69. Govindan, K.; Shankar, K.M.; Kannan, D. Achieving sustainable development goals through identifying and analyzing barriers to industrial sharing economy: A framework development. Int. J. Prod. Econ. 2020, 227, 1-13. [CrossRef]

70. Arfi, W.B.; Hikkerova, L. Corporate entrepreneurship, product innovation, and knowledge conversion: The role of digital platforms. Small Bus. Econ. 2019, 1-14. [CrossRef]

71. Bolesnikov, M.; Popović Stijačić, M.; Radišić, M.; Takači, A.; Borocki, J.; Bolesnikov, D.; and Dzieńdziora, J. Development of a Business Model by Introducing Sustainable and Tailor-Made Value Proposition for SME Clients. Sustainability 2019, 11, 1157. [CrossRef]

72. Li, M.; Lin, P.; Xu, G.; Huang, G.Q. Cloud-based ubiquitous object sharing platform for heterogeneous logistics system integration. Adv. Eng. Inform. 2018, 38, 343-356. [CrossRef] 
73. Reitmaier, L.; Ou, T.; Tsai, C.; Sanchez, J. Implementing a Platform-service based on Sharing Economy for Supply Chain Operations of Small and Medium Enterprises. In Transdisciplinary Engineering: A Paradigm Shift, Proceedings of the 24th ISPE Inc. International Conference on Transdisciplinary Engineering, Singapore, Singapore, 10-14 July 2017; IOS Press: Amsterdam, The Netherlands, 2017; pp. 94-101.

74. ULAS, D. Digital Transformation Process and SMEs. Procedia Comput. Sci. 2019, 158, 662-671. [CrossRef]

75. Gong, D.; Liu, S.; Liu, J.; Ren, L. Who benefits from online financing? A sharing economy E-tailing platform perspective. Int. J. Prod. Econ. 2020, 222, 1-10.

76. Hamidi, F.; Shams Gharneh, N.; Khajeheian, D. A Conceptual Framework for Value Co-Creation in Service Enterprises (Case of Tourism Agencies). Sustainability 2020, 12, 213. [CrossRef]

77. Hur, E. Collaborative consumption for small and medium-sized fashion enterprises in South Korea. In Global Perspectives on Sustainable Fashion; Bloomsbury Publishing: London, UK, 2019; pp. 148-159.

78. Xu, G.; Li, M.; Chen, C.H.; Wei, Y. Cloud asset-enabled integrated IoT platform for lean prefabricated construction. Autom. Constr. 2018, 93, 123-134. [CrossRef]

79. Yu, T.; Shen, W. Funds sharing regulation in the context of the sharing economy: Understanding the logic of China's P2P lending regulation. Comput. Law Secur. Rev. 2019, 35, 42-58. [CrossRef]

80. Koberidze, A. Particularities of Doing Business in Russia in the Conditions of Sharing Economy. In Proceedings of the 2018 2nd International Conference on Economic Development and Education Management (ICEDEM 2018), Dalian, China, 29-30 December 2018; Atlantis Press: Paris, France, 2018; Volume 290, pp. 366-369.

81. Nathan, R.J.; Victor, V.; Gan, C.L.; Kot, S. Electronic commerce for home-based businesses in emerging and developed economy. Eurasian Bus. Rev. 2019, 9, 463-483. [CrossRef]

(C) 2020 by the authors. Licensee MDPI, Basel, Switzerland. This article is an open access article distributed under the terms and conditions of the Creative Commons Attribution (CC BY) license (http://creativecommons.org/licenses/by/4.0/). 